\title{
CORPORATE SOCIAL RESPONSIBILITY AND SUSTAINABLE TOURISM
}

\author{
Jyotirmoy Ghosh*, G. Anjaneyaswamy**
}

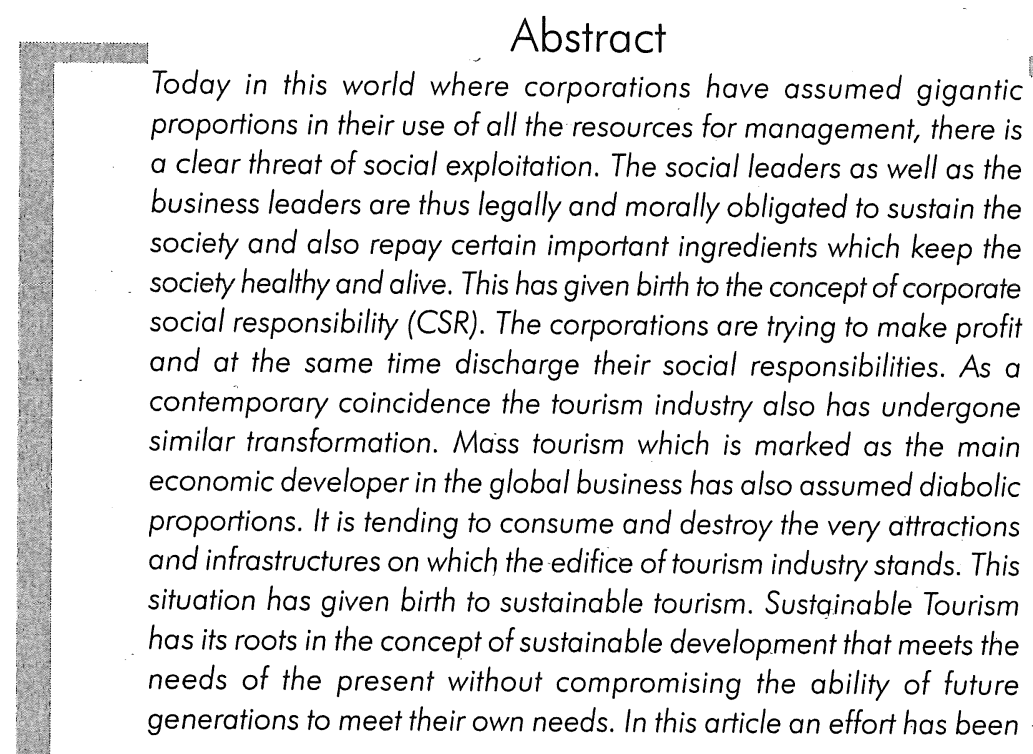

* Associate Professor, Dept of Hotel Management, Christ University, Bangalore.

** Professor \& Head, Dept of Tourism Studies, Pondicherry University, Puducherry. 
made to showcase the striking similarities of CSR and sustainable tourism. In the global business context the future generations should practice responsibility and a sustainable form of tourism to save their respective businesses and planet earth.

\section{Introduction}

Over the past three decades, social responsibility has emerged as a major issue. Although it takes different forms for different industries and companies, the basic challenge exists for all. Social responsibility consists of obligations that a business has to society. Corporate Social Responsibility (CSR) is a concept that organizations, specially (but not only) corporations have an obligation to consider the interests of customers, employees, shareholders, communities and ecological considerations in all aspects of their operations. This obligation is seen to extend beyond their statutory obligations to comply with legislation. CSR is closely linked with the principles of sustainable development, which argues that enterprises should make decisions based not only on financial factors such as profits or dividends, but also based on the immediate and long-term social and environmental consequences of their activities.

The tourism industry advocates sustainable development and has promoted sustainable tourism for the last two decades much on the same lines of Corporate Social Responsibility (CSR). Enterprises of all sizes and types help to shape the perceptions and behaviour of individual tourists, influence residents quality of life through wage relation and the use of local resources, and often attempts to influence public policy. Eminent sustainable tourism expert Butler defines sustainable tourism as "Tourism which is developed and maintained in an area (community, environment) in such a manner and at such a scale, that it remains viable to cover an indefinite period and does not degrade or alter the environment (human and physical) in which it exists to such a degree that it prohibits the successful development and well being of other activities and process."

So we can clearly see CSR and sustainable tourism fulfil common objectives. In this particular study, efforts will be made to showcase various global tourism activities that are executed in the sustainable development mould. Research reports will also be expressed to show the extent of Corporate Social Responsibility obligations actually fulfilled by the tourism organizations. 


\section{Analysis of CSR Concept}

The World Business Council for Sustainable Development states that "Corporate Social Responsibility is the continuing commitment by business to behave ethically and contribute to economic development while improving the quality of life of the workforce and their families as well as of the local community and society at large". This holistic approach to business regards organizations as being full partners in their communities, rather than seeing them more narrowly as being primarily in business to make profits and serve the needs of their shareholders. Social Responsibility consists of obligations a business has to the society. These obligations extend to [many] different areas. According to Richard M. Hodgetts and Donald F. Kuratko, these aspects are as follows:

\section{Chart Showing Scope of Social Responsibility}

\section{Environment}

- Pollution control.

- Restoration or protection of environment.

- Conservation of natural resources.

- Recycling effort.

\section{Energy}

- Conservation of energy in production and marketing operations.

- Efforts to increase the energy efficiency of products.

- Other energy-saving programs (for example, company-sponsored car pools).

\section{Fair Business Practices}

- Employment and advancement of women and minorities.

- Employment and advancement of disadvantaged individuals.

- Support for minority-owned businesses. 


\section{Human Resources}

- Promotion of employee health and safety.

- Employee training and development.

- Remedial education programs for disadvantaged employees.

- Alcohol and drug counselling programs.

- Career counselling.

- Child day-care facilities or working parents.

- Employee physical fitness and stress management programs.

\section{Community Involvement}

- Donations of cash, products, services or employee time.

- Sponsorship of public health projects.

- Support of education and the arts.

- Support of community projects (recycling centres, disaster assistance, and urban renewal).

\section{Products}

- Enhancement of product safety.

- Sponsorship of product safety education programs.

- Reduction of polluting potential products.

- Improvement of nutritional value of products.

- Improvement in packaging and labelling.

The vast diversity of Social Responsibility makes one wonder to what extent corporations should be involved.

Presently the ever expanding interest of the role of business in society has been promoted by increased sensitivity to and awareness of environmental and ethical issues. Issues like environmental damage, improper treatment of workers, and faulty production that cause inconveniences or endangers customers are highlighted in 
the media. In some countries, government regulations regarding environmental and social issues have increased. Also, standards and laws are often set at a supranational level (e.g. by the European Union). Some investors and investment fund managers have begun to take account of corporation's CSR policy in making investment decision. Some consumers have become increasingly sensitive to the CSR performance of the companies from which they buy their goods and services. These trends have contributed to the pressure on companies to operate in an economically, socially and environmentally sustainable way.

We should distinguish CSR from charitable donations and good works (i.e. philanthropy and habitat for humanity). Corporations have offen in the past, spent money on community projects, the endowment of scholarships and the establishment of foundations. They have also encouraged their employees to volunteer, to take part in community work and thereby create goodwill in the community, which will directly enhanice the reputation of the company and strengthen its brands. CSR goes beyond charity and requires that a responsible company takes into account its impact on all stakeholders and on the environment when making decisions. This requires that the company should balance the needs of all stakeholders, with its need to make a profit and reward shareholders adequately.

\section{Development of Sustainable Tourism}

The concept of sustainability came to public attention for the first time with the publication of the World Conservation Strategy (WCS) in March 1980 (IUCN 1980). The WCS was prepared by the International Union for conservation of Nature and Natural Resources (IUCN) with the assistance of the United Nations Environment Education Programme (UNEP), the World Wildlife Fund (WWF), the Food and Agriculture Organization of the United Nations (FAO) and the United Nations Educational, Scientific and Cultural Organization (UNESCO). The WCS was a strategy for the conservation of earth's living resources in the face of major international environmental problems such as deforestation, desertification, ecosystem degradation and destruction, extinction of species and loss of genetic diversity, loss of cropland, pollution and soil erosion. The WCS was developed by a combination of government agencies and non-government organizations and individual experts from over 100 countries.

The WCS defined conservation as "the management of human use of the biosphere so that it may yield the greatest sustainable benefit to present generations which maintaining its potential to meet the needs and aspirations of future generations" (IUCN 1980, S.I.6). The WCS had three specific objectives: 
1. To maintain essential ecological process and life-support systems (such as soil regeneration and production with the recycling of materials and the cleansing of waters), on which human survival and development depend.

2. To preserve genetic diversity (the range of genetic material found in the world's organization), on which depend the breeding programs necessary for the protection and improvement of cultivated plants and domesticated animals, as well as scientific advancements, technical innovations, and the security of many industries that use living resources.

3. To ensure that sustainable utilization of species and ecosystems (notably fish and other wildlife, forest and grazing lands), which support millions of rural communities as well as major industries.

The WCS was also significant in that it represented the halfway mark between the 1972 United Nations Stockholm Conference on the Human Environment and the 1992 UN Conference on Environment and Development (UNCED) in Rio de Janeiro (often referred to as 'The Rio Summit'). The WCS can be regarded as a product of the Stockholm Conference, as one of the institutional results of the meeting was the establishment of the UNEP, which had substantial influence on the formulation of the WCS. In addition to assisting in the development and promotion of the WCS, the UNEP promoted the idea of the creation of a World Commission of Environment and Development (WCED) at its ten-year review conference in 1982.

According to the WCED (1987:43) sustainable development is development that 'meets the needs of the present without compromising, the ability of future generations to meet their own needs'. Five basic principles of sustainability were identified in the report.

1. The idea of holistic planning and strategy making.

2. The importance of preserving essential ecological processes.

3. The need to protect both human heritage and biodiversity.

4. To develop in such a way that productivity can be sustained over the long term for future generations.

5. Achieving a better balance of fairness and opportunity between nations.

Achievement of sustainable development also heralded a change in lifestyle in Western Countries, not only to place less presume on the use of non-renewable resources but also to assist in the transfer of funds from the North to the South 
(WCED 1987). The concept of sustainable development therefore provides a substantial challenge to the people and governments of Western Nations.

The sustainable development guru Ekins expresses that certain conditions are to be rigorously adhered to, with respect to resources use, pollution and environmental control, to ensure that economic activities are environmentally sustainable. These are:

- Destabilization of global environment features such as climate patterns and the ozone layer must be prevented.

- Important ecosystems and ecological features must receive absolute protection in order to maintain biological diversity.

- Renewable resources must be maintained with sustainable harvesting measures rigorously enforced.

- Non-renewable resources must be used as intensively as possible.

- Depletion of non-renewable resources should proceed on the basis of maintaining minimum life expectancies of such resources, at which level consumption should be matched by new discoveries of these resources and technological innovation.

- Emissions into the biosphere should not exceed the biosphere's capacity to absorb such emissions.

- Risk of life-damaging events from human activity, e.g. Nuclear power generation must be kept at very low levels.

Thus we can see, meeting such conditions for sustainability is a major political, economic and environmental issue as it requires new ways of thinking about the nature and purpose of development and growth, and the role of individuals, government and the private sector in developing sustainable future is a concern that is increasingly at the forefront in the analysis of tourism.

\section{Notable Milestones of International Sustainable Tourism}

International Tourism has shaped itself within a number of sustainable regulations over the years. It is worthwhile to discuss some of these notable regulations: 
- General Assembly Resolution of 1962 on Permanent Sovereignty over Natural Resources Resolution 1803 (of UN) - The right people and nations to permanent Sovereignty over their natural wealth and resources must be exercised in the interest of their national development and the well-being of the people of the state concerned.

- The World Charter for Nature, 1982 (of UN) - Man must acquire the knowledge to maintain and enhance his ability to use natural resources in a manner which ensures the preservation of the species and ecosystems for the benefit of present and future generations.

- Declarations of the United Nations Conference on the Human Environment 1972 - Man is both creature and moulder of his environment, which gives him physical sustenance and affords him the opportunity for intellectual, oral, social and spiritual growth.

- United Nations Educational, Scientific and Cultural organization convention for the protection of the world cultural and Natural Heritage and the World Heritage List. 1972 - It is essential to adopt new provisions in the form of convention and natural heritage of outstanding universal value, organized on a permanent basis and in accordance with modern scientific methods.

- Convention on the Conservation of Migratory Species of Wild Animals (1980) (of UN) - Wild Animals in their innumerable forms are an irreplaceable part of the earth's natural system which must be considered for the good of mankind.

- Convention of wetlands of international importance especially as waterfowl habitat (1971) (of UN) - Multi-disciplinary international research in recent years has shown convincingly the unrivalled value of the Wadden sea as a natural resource because of its high biological productivity and its geographical situation as it is of vital importance for literally millions of Eurasian waterfowl. This area in the territories of Denmark, the Federal Republic of Germany and the Netherlands is threatened by development plans involving the construction of dams and dykes, the establishment of industries and other human impacts which are altering the present ecological situation.

- Convention on International Trade in Endangered Species of Wild Fauna and Flora, as amended in 1977.

- International rules and National Legislation to prevent, reduce and control pollution of the Marine Environment (sec 5. Art. 207) - states shall adopt laws and regulations to prevent, reduce and control pollution of the marine environment from land-based sources, including rivers, estuaries, pipelines 
and outfall structures, taking into account internationally agreed rules, standards and recommended practices and procedures.

- International cooperation to accelerate sustainable development in developing countries. (section 1, chapter 2 of Agenda 21)-combating poverty (sec 1, chapter 3 of Agenda 21) - changing consumption patterns (sec 1, chapter 4 of-Agenda 21)-Demographic Dynamics and Sustainability (sec 1, chapter 5 of Agenda 21) - Protecting and promoting Human Health (sec 1, chapter 6 of Agenda 21) - Promoting sustainable human settlements (sec 1, chapter 7 of Agenda 21) - Policy Making for Sustainable Development (sec 1, chapter 8 of Agenda 21).

- Protecting the atmosphere: Making the energy transition (sec II, chapter 9 of Agenda 21) - To protect the atmosphere four programmes are essential:

1. Uncertainties in related scientific knowledge.

2. Sustainable development with regard to energy, transport, industry, and land and marine resources.

3. Stratospheric ozone depletion and

4. Trans-boundary air pollution.

- An integrated approach to land - resource use (sec II, ch 10, Agenda 21).

- Combating deforestation (sec II, ch 11, Agenda 21).

- Halting the spread of Deserts (sec II, ch 12, Agenda 21).

- $\quad$ Protecting Mountain Ecosystems (sec II, ch 13, Agenda 21).

- Meeting Agricultural Needs without destroying the land (sec II, ch 14, Agenda 21).

- Sustaining Biological Diversity (sec II, ch 15, Agenda 21).

- Environmentally Sound Management of Biotechnology (sec II, ch 16, Agenda 21).

- Safeguarding the Ocean's Resources (sec II, ch 17, Agenda 21).

- Protecting and Managing Freshwater Resources (sec II, ch 18, Agenda 21).

- $\quad$ Safe use of Toxic Chemicals (sec II, ch 19, Agenda 21). 
- Managing Hazardous waste problems (sec II, ch 20, Agenda 21).

- Seek solutions to solid waste problems (sec II, ch 21, Agenda 21).

- Management of Radioactive wastes (sec II, ch 22, Agenda 22).

- Action for women, sustainable and equitable Development (sec III, ch 24, Agenda 21).

- Social partners for sustainable development (sec III, ch 25-32, Agenda 21).

- Financial Resources and Mechanisms (sec IV, ch 33, Agenda 21).

- Making environmentally sound technology available to all (sec IV, ch 34, Agenda 21).

- Science for sustainable development (sec IV, ch 35, Agenda 21).

A study of the above mentioned regulations will reveal the extent of sustainable controls the tourism industry is already subjected to. The regulations are followed diligently by Hotels, Airlines, Railways, Ships and Cruises, tourist cars and coach companies and all the travel and tour operators. All major companies catering to the tourism industry adhere to all the stringent sustainable measures. Hotels regularise environment issues by maintaining proper land use, pollution free zone, garbage recycle or proper disposal; retain from discharging toxic fumes, plastic free zones, energy conservation, use of alternate energy sources as solar and biogas, abundant greenery and landscaping, waste water recycling, use of bio-degradable cleaning agents and so on.. Hotel managements also fulfil the social obligation for sustainability by training and employing local people, providing quality employment for women, keeping the work hazard and accident free, providing healthy and hygienic food products to customers and staff, ensuring high standards of cleanliness and public hygienic and so on. Thus major international hotel chains as the Hiltons, Sheratons, Marriott's, Radissons and Four Seasons are practicing Corporate Social Responsibility (CSR) as a matter of regular practice. Similarly the international cruise liners are forced to maintain the sea laws, the marine life protection, to restrain from discharging toxic and radioactive waste into the sea and so on as environmental measure. The social measures are enforced by fairness in salary and wages, maintaining a fair ratio of male and female on work, introducing good labour laws, curbing criminal and immoral activities on board and so on. The cruise companies actively follow Corporate Social Responsibility (CSR) to survive and to prosper.

We have to now explore into sustainable tourism in a particular destination to find out signs of CSR. 


\section{Sustainable Tourism at Bermuda}

We present an appropriate case study in this context. Situated in the Atlantic Ocean, Bermuda resembles a Caribbean Island in size, topography, colonial history and tourism dependence. Tourism in Bermuda developed as early as post First World War and post Second World War due to affluent passengers from Europe and America travelling by steam ships. The introduction of a modern airport paved the way for mass tourism which peaked during the 1980s.

Bermuda went through sustainable development over a generation, and transformed into the most affluent destination in the region. The island exhibits all the characteristics associated with the mature high-density stage of the resort cycle. These traits include slow economic and population growth and flat or declining tourist arrivals, heavy, dependence on short-staying ( 90 percent North American) visitors who are dominantly hotel guests (nearly 70 percent), a large-scale hotel plant with nearly 70 percent of all rooms in large (100 room) hotels, high occupancy rates (60-70 percent) expanding manmade attractions like, shopping complexes, and a share of one-day cruise visitors.

Bermuda still remains noted for its British country side quaintness, political stability, sophisticated and genuinely friendly populaces and distinctive and maintained environment, pink sand beaches lush greenery, pastel-coloured homes, historical architectures, safety and order, and above all, its immaculately clean and uniquely trimmed landscape. As a result, Bermuda's image endures as a distinctive, quaint, upscale destination for sophisticated travellers seeking quality and charm.

The reality and sustainability of this image is less fortuitous and more the result of conscious planning and community awareness. During the late 1970s and 1980s increasing crowding, particularly from cruise ship trade, stimulated efforts to control visitor densities and protect the island's natural and cultural patrimony. A moratorium on new bedroom capacity was imposed and cruise traffic curtailed. Specific ordinances were enacted and strictly enforced to preserve special vistas, delicate natural areas and historical sites. Local materials and native vegetation were mandated for residential construction and landscaping. These planning initiatives had the widespread support of local residents who felt that Bermuda was suffering from visitor saturation and who viewed, the island's pristine appearance as extremely important not only for the quality of tourism but also for their own quality of life.

Clearly as more sustainable insular tourism will require a different approach from the tradition as mass syndrome; rising scale, promotion and densities associated with declining visitor repeats, satisfaction, assets and service quality fostering ever renewed rounds of more resort cycle. Contemporary trends expected to intensify 
over the next decade include an expanded demand for more pristine, natural and authentic cultural education experiences by an increasingly sophisticated clientele with more travel options available, and a more sharply competitive climate as both mature, intermediate and emerging destinations vie for market share.

\section{Conclusion}

Today's heightened interest in the role of business in society has been promoted by increased sensitivity to and awareness of environmental and ethical issues. Corporate bodies are expected to give back to the society its due as they have taken almost everything from the society. The stakeholders of companies and the consumers feel that the organizations should make profit for survival and growth but at the same time offer sustenance for the environment within which it thrives. Thus terms such as Corporate Governance and Corporate Social Responsibility have become a buzzword among professionals. Sustainable Tourism probably emerged from CSR concerns and also has developed over the years with the CSR mantra.

\section{References}

Report of the United Nations Conference on Environment and Development, Rio de Janeiro 3-14 June 1.992, vol. 1, Resolutions adopted by the conference (United Nations Publication, sales No. E.93.1.8 and corrigendum), resolution I, annex II.

Judith Kenner Thompson and Howard L. Smith, 'Social Responsibility and Small Business: Suggestions for Research', Journal of Small Business Management (January 1991): 30-44.

Erika Wilson, 'Social Responsibility of Business: What are the Small Business Perspectives?' Journal of Small Business Management (July 1980) 17-24.

Richard M. Hodgetts and Donald F. Kuratko, 'Management', $3^{\text {rd }}$ (San Diego: Harcourt Brace Jovanorich, 1991), 670.

Tourism Concern/World Wildlife Fund (1992) 'Beyond the Green Horizon: Principles for sustainable Tourism', Tourism Concern, Godalming.

Blamey, R.K. and Braithwaite, V.A. (1997) 'A social values segmentation of the potential ecotourism market', Journal of Sustainable Tourism 5(1), 29-45.

Davis, K. and Blomstrom, R. (1975) 'Business and Society: Environment and Responsibility', McGraw-Hill, New York.

Carroll, A. and Buchholty, A. (2003) 'Business and Society: Ethics and Stakeholder Management', Thomson, Ohio. 